\title{
WOJCIECH LEWANDOWSKI ${ }^{*}$
}

\section{PROBLEM INTERPRETACJI ZASADY FIAT IUSTITIA, RUAT COELUM}

Słowa kluczowe: fiat iustitia, ruat coelum, absolutyzm, sprawiedliwość, katastrofa Keywords: fiat iustitia, ruat coelum, absolutism, justice, catastrophe

„Niech sprawiedliwości stanie się zadość, choćby miały zapaść się niebiosa”. Powyższa sentencja, jak i podobna do niej: „Niechaj dokona się sprawiedliwość, choćby świat miał przepaść" (fiat iustitia, pereat mundus), ma długą historię w dziejach zasad etycznych, a jednocześnie stanowi przedmiot poważnych kontrowersji. Początków tej zasady upatruje się w filozofii stoickiej. Ideał człowieka sprawiedliwego, nielękającego się tragicznych konsekwencji, przedstawiony jest w odzie Horacego Iustum et tenacem:

Sprawiedliwego, który trwa przy swoim,

Nie zwiedzie z drogi ni thum rozwydrzony i żądny zbrodni,

* Wojciech Lewandowski - doktor filozofii, adiunkt w Instytucie Filozofii Katolickiego Uniwersytetu Lubelskiego Jana Pawła II. Autor książki Przyszłość i odpowiedzialność. Problem uzasadnienia odpowiedzialności za przyszłe pokolenia we współczesnej etyce (Lublin, 2015).

Address for correspondence: John Paul II Catholic University of Lublin, Al. Racławickie 14, 20-950 Lublin. E-mail: wojciech.lewandowski@kul.pl. 
ni tyrana widok nie zdoła zachwiać, ni wiatr, co wzburzone podnosi morze, od południa dmący,

Ani Jowisza dłoń, co piorun ciska:

Gdyby glob ziemski roztrzaskał się w drzazgi,

On, nieustraszon, zginąłby w zwaliskach ${ }^{1}$.

Różne wersje tej zasady mają również swój udział w rozwoju nowożytnej myśli politycznej i prawnej. Fiat iustitia et pereat mundus było mottem Ferdynanda I Habsburga, William Watson uznał sformułowanie fiat iustitia et ruant coeli za ogólną maksymę prawa (Watson, 1602, s. 245), zaś William Murray Mansfield fiat iustitia, ruat caelum użył przy uzasadnieniu priorytetu zasad sprawiedliwości nawet w obliczu możliwej rebelii (Mansfield, 1770, s. 2561 i n.) $)^{2}$.

Przy wstępnej próbie zrozumienia tej zasady nasuwają się dwie podstawowe możliwości jej interpretacji. Po pierwsze można ją traktować jako regułę praktyczną określającą, jak postępować w sytuacjach konfliktowych: jeśli zabójstwo jest absolutnie zakazane, to nie możemy go popełnić nawet wówczas, gdy chcemy ocalić od śmierci większą liczbę ludzi. W tym pierwszym sensie omawiana zasada zwykle nie pełni pozytywnej funkcji argumentacyjnej. Widać to zwłaszcza w dyskusji między reprezentantami konsekwencjalizmu i deontologizmu przyjmującego absolutny charakter norm moralnych. Pierwsi na ogół traktują fiat iustitia jako ostateczny test dla absolutyzmu. Każdy, kto utrzymuje, że normy moralne obowiązują bez wyjątków, w końcu musi zmierzyć się z tragiczną alternatywą: sprawiedliwość albo uniknięcie katastrofy ${ }^{3}$. Nie ma więc nic dziwnego w tym, że również deontologiści podchodzą do omawianej zasady z rezerwą, dodając do moralnych ograniczeń klauzulę katastrofy (Fried, 1978, s. 10).

Po drugie zasadę fiat iustitia, ruat coelum można rozumieć jako ogólny sąd moralny, nie odnoszący się wprost do konkretnych decyzji, lecz ukazujący bezwzględną wartość sprawiedliwości. Sytuacje konfliktowe są

1 Flaccus Quintus Horaccius (1967). Instum et tenacem propositi virum. Tłum. I. Wieniewska. W: tenże, Wybór poezji. Oprac. J. Krókowski. Wrocław: Ossolineum.

2 Historię tej zasady szczegółowo przedstawia Detlef Liebs (2014).

3 Podobnie konflikt ten jest ujmowany przy interpretowaniu fiat iustitia we współczesnej filozofii prawa. Zasada ta jest interpretowana jako postulat nieliczącego się z kosztami legalizmu, przyznającego sprawiedliwości nadrzędne miejsce nad pozostałymi celami prawa: bezpieczeństwem i celowością (Zajadło, 2013, s. 39 i n.; Radbruch, 1937, s. 325). 
w tym wypadku jedynie kontekstem, w którym wartość ta uwyraźnia się najbardziej. W tej interpretacji zasada powyższa byłaby więc hiperbolą stanowiska deontologicznego. Jak się wydaje, w ten sposób rozumiał ją Jeremy Bentham, który jednak - choć doceniał jej walory retoryczne-zdecydowanie ją odrzucał jako wyraz nonszalancji wobec konsekwencji naszych działań (Bentham, 1789/2005, s. 22). Podobnie rozumiał ją, nieco przychylniej do niej nastawiony, Henry Sidgwick. Jego zdaniem zasady takie jak fiat iustitia, ruat coelum wskazują jedynie, że kalkulacja zysków i strat nie jest potrzebna do tego, by wiedzieć, jakie są nasze obowiązki (Sidgwick, 1907, s. 200). Zasada ta nie wystarcza jednak to określenia, co powinniśmy robić w konkretnych okolicznościach, zwłaszcza w sytuacji konfliktu obowiązków.

Niniejszy artykuł dotyczy pytania o to, czy możliwa jest pozytywna interpretacja fiat iustitia, ruat coelum, która pozwoliłaby na zastosowanie tej zasady w rozstrzyganiu praktycznych problemów moralnych. Aby na to pytanie odpowiedzieć, wyróżnię dwa podstawowe elementy zasady fiat iustitia, ruant coeli: zapadnięcie się niebios oraz dokonywanie się sprawiedliwości. Każdy z tych elementów może podlegać różnym interpretacjom, stąd w dalszej części artykułu postaram się odpowiedzieć kolejno na pytania: jak można rozumieć zapadnięcie się niebios oraz jak można rozumieć sprawiedliwość. Następnie, w trzeciej części artykułu, przedstawię przykład sytuacji, w której absolutystyczna intuicja stojąca za fiat iustitia, ruat coelum wydaje się najsilniejsza.

\section{Zapadnięcie się niebios}

Interpretacje zapadnięcia się niebios mogą pojawić się w dyskusjach etycznych w trzech kontekstach. W perspektywie indywidualnej ,zapadnięciem niebios" jest własna śmierć, która jest katastrofą nie mniej straszliwą niż zagłada całego świata. Zgodnie z fiat iustitia powinniśmy wybierać sprawiedliwość nawet wtedy, gdyby miało się to zakończyć naszą śmiercią. W perspektywie indywidualnej zasada fiat iustitia nie budzi więc kontrowersji. Jesteśmy skłonni podziwiać osoby, które trzymają się uznawanych zasad, nawet w obliczu utraty życia lub wszystkiego, co jest dla nich drogie. Trudności pojawiają się wówczas, gdy katastrofą zagrożone jest nie tylko nasze własne życie, lecz również reszta świata. 
Drugim kontekstem, w jakim przywoływana jest zasada fiat iustitia, jest ryzyko globalnej katastrofy rozumianej albo jako nieodwracalne zniszczenie środowiska naturalnego, albo jako wyginięcie gatunku ludzkiego. Ta bliska dosłowności interpretacja „przepadnięcia świata” odnosi się do wciąż powiększających się ludzkich możliwości. Związane z nimi ryzyko sprawia, że ewentualność tragicznego finału postępu naukowo-technicznego wielu autorom nie wydaje się przesadzona. Na realność zagrożenia definitywną katastrofą zwraca uwagę m.in. Hans Jonas, dla którego stanowi ona przesłankę, by odrzucić omawianą zasadę. W nowych warunkach, w jakich znalazła się ludzkość, należy stworzyć ,nową etykę”, uwzględniającą ryzyko „zapadnięcia się niebios” i opartą na tzw. heurystyce strachu, dzięki której możliwe jest odkrycie wartości wymagających absolutnej ochrony (Jonas, 1997, s. 36).

Trzecim kontekstem, w którym można mówić o zawaleniu się niebios, jest śmierć lub cierpienie innych ludzi lub największa utrata znaczących pozamoralnych dóbr. Jeśli rygorystyczne trzymanie się zasad moralnych miałoby prowadzić do katastrofalnych skutków, śmierć setek lub tysięcy osób wydaje się zbyt wysoką ceną za spokojne sumienie i „czyste ręce” podmiotu moralnego. Jakakolwiek koncepcja sprawiedliwości, która dopuszczałaby bierność wobec groźby ogromnej katastrofy, byłaby zgodnie z konsekwencjalnymi założeniami nie do przyjęcia, zaś sentencjafiat iustitia, ruat coelum nie byłaby wyrazem godnej pochwały wierności wyznawanym zasadom, lecz fanatycznego zaślepienia.

Możliwe postawy wobec zapadnięcia się niebios mogą odwoływać się do następujących założeń:

1. Istnieje racja za tym, by unikać zapadnięcia się niebios (UZN).

2. Istnieje racja za tym, by zaakceptować zapadnięcie się niebios (ZZN).

Racja UZN jest akceptowana zarówno w moralności zdroworozsądkowej, jak i na gruncie teorii etycznych. W całości akceptują ją stanowiska konsekwencjalne. W przypadku stanowisk niekonsekwencjalnych racja ta jest przyjmowana na jeden z trzech sposobów: a) jako nadrzędna wobec pozostałych racji, również moralnych, b) jako akceptowana prima facie na równi z pozostałymi racjami praktycznymi lub c) jako podporządkowana absolutnym wymogom moralnym. Pierwszy sposób jest przyjmowany przez autorów, którzy przyjmują klauzulę katastrofy, drugi - przez tych, którzy 
wskazują na możliwość ważenia racji. Większość zarzutów przeciwko zasadzie fiat iustitia wydaje się dotyczyć przyjęcia UZN na trzeci sposób.

Podobne różnice występują w rozumieniu ZZN. Na pierwszy rzut oka racja ta mogłaby zostać przyjęta tylko przy ograniczeniu jej do sytuacji, w której nie możemy zapobiec katastrofie. W tej interpretacji ZZN nie byłaby przeciwstawna UZN, ponieważ ich zakres byłby rozłączny. Racjonalne jest unikanie katastrofy wtedy, gdy jest to możliwe, i akceptacja jej, gdy nie da się jej uniknąć. Za ZZN przemawiałby fakt, że podejmowanie bezowocnych wysiłków w celu odwrócenia nieuniknionego jest bezcelowe, zaś pozostały nam czas lepiej jest wykorzystać w inny sposób. Rozłączność zakresu UZN i ZZN nie oznacza, że im silniejsza jest ta pierwsza, tym słabsza druga, i na odwrót. Możliwe są sytuacje, w których podmiot lub grupa podmiotów traktuje je obie jako równie słabe bądź równie silne. W pierwszym wypadku jego preferencje są bliskie całkowitej obojętności, a perspektywa nicości jest równie mało atrakcyjna jak perspektywa pozbawionego sensu istnienia lub też środki pozwalające uniknąć śmierci są dla niego zbyt wymagające w zestawieniu z tym, co obiecuje kontynuacja istnienia. Fiat iustitia wydaje się zakładać drugi przypadek, w którym zarówno istnieje bardzo silna racja za uniknięciem katastrofy, jak i co najmniej równie silna racja za niepodejmowaniem działań, które mogłyby jej zapobiec.

Kontrowersje wokół fiat iustitia dotyczą prób zastosowania ZZN w sytuacjach, w których moglibyśmy uniknąć katastrofy, łamiąc wymogi moralności. Zauważmy jednak, że zasada ta nie polega na odrzuceniu UZN. Wydaje się, że absolutyzm akceptujący UZN może przyjmować zasadę analogii powinności i możliwości.

Zasada analogii powinności i możliwości - fakt, że dane działanie jest zakazywane przez absolutną normę moralną, powinien być traktowany tak jak brak możliwości wykonania tego działania.

Jeśli nie istnieje możliwość uniknięcia katastrofy za pomocą moralnie dopuszczalnych środków, należy ją zaakceptować, tak jak gdyby nie istniały żadne środki. Osobie przyjmującej tę zasadę można zarzucić, że nie jest racjonalne traktowanie dwóch wykluczających się faktów (istnieje możliwość/nie istnieje możliwość) w ten sam sposób. W odpowiedzi absolutysta może stwierdzić, że jego rozumowanie nie polega na pewnego rodzaju samookłamywaniu się (,nie mogę myśleć o tym, że mam tę możliwość”), lecz na tym, że środki niespełniające kryteriów moralnych nie przechodzą do etapu namysłu nad możliwymi opcjami działania. Przyjęcie powyższej 
zasady wymaga zmiany rozumienia ZZN. Jeśli w omawianym kontekście nie opiera się ona na bezcelowości wysiłków zmierzających do uniknięcia katastrofy, absolutysta ma dostępne dwie strategie, by ją utrzymać. Pierwszą jest przyjęcie założenia o związku między dokonywaniem się sprawiedliwości a pozytywnym stanem świata. Założenie to może mieć oparcie w stanowisku teistycznym, głoszącym, że gwarantem tego związku jest Bóg, jednak jak zobaczymy, założenie o tym związku jest przyjmowane nie tylko w absolutystycznych interpretacjach fiat iustitia. ZZN w tym ujęciu będzie rozumiane jako nieunikniony, choć nie ostateczny koszt utrzymania sprawiedliwości w świecie lub jako test dla prawości podmiotów moralnych. Według Alana Donagana fiat iustitia została sformułowana w kulturze przyjmującej, że niebiosa nie mogą upaść przez czynienie sprawiedliwości. Jest ona częścią tradycyjnej moralności opartej na ostrożnym rozważeniu natury ludzkiego działania i świata, w którym się ono dokonuje (Donagan, 2014, s. 206 i n.). Zdaniem Alana Wheelera taka próba uczynienia fiat iustitia przekonującą, stanowi jej faktyczne odrzucenie (Wheeler, 1986, s. 874). Słowa „choćby niebiosa miały się zapaść" miałyby wówczas jedynie sens metaforyczny, a cała zasada nie mogłaby być stosowana do rozstrzygania szczegółowych problemów.

Drugą strategią jest przyjęcie stanowiska pesymistycznego, zakładającego brak wskazanego wyżej związku. ZZN oznaczałoby wówczas zaakceptowanie faktu, że żyjemy w świecie, w którym sprawiedliwość nie jest i nie będzie nagrodzona. Przy tym założeniu bycie moralnym podmiotem oznacza bycie bohaterem tragicznym. W świetle tej interpretacji nie oznacza to jednak, że powinniśmy zrezygnować z tej roli. Bohater ody Horacego nie przestaje być moralnym ideałem tylko dlatego, że ostatecznie ponosi porażkę. Według Maxa Schelera sytuacje tragiczne są możliwe tylko wtedy, gdy porządek wartości wchodzi w konflikt w z porządkiem przyczynowym. Świat „diabelski”, w którym sprawiedliwość zawsze prowadziłaby do katastrofy, tak samo wykluczałby tragiczność, jak świat doskonale boski, w którym sprawiedliwość zawsze byłaby nagradzana (Scheler, 1976, s. 73). Jak zobaczymy, choć pierwsza strategia jest częściej zakładana w interpretacjach fiat iustitia, to stojąca za nią absolutystyczna intuicja daje się pogodzić wyłącznie z drugą. Perspektywa katastrofy musi jawić się nie jako odległa i hipotetyczna ewentualność, lecz jako realny scenariusz prowadzący do ostatecznej nicości, który należy zaakceptować lub spróbować go uniknąć, podejmując moralnie niesłuszne działania. 
Ważną kwestią dla interpretacji fiat iustitia jest pytanie o charakter racji UZN i ZZN. Dość łatwo jest przyjąć, że UZN jest neutralna wobec podmiotu: każdy podmiot nie tylko ma powód, by unikać katastrofy, lecz również by zapewnić taki stan rzeczy, w którym inni starają się jej uniknąć. Uznanie neutralnego charakteru ZZN zależy od odpowiedzi na pytanie, czy każdy podmiot ma powód do dążenia, by inni nie podejmowali bezcelowych wysiłków lub by przyjęli zasadę analogii możliwości i powinności. Wydaje się, że na obie części tego pytania można odpowiedzieć twierdząco. Fakt, iż inni podejmują bezcelowe wysiłki wydaje się należeć do tej samej kategorii co fakt, że doświadczają oni cierpienia. Oba przypadki stanowią rację do udzielenia pomocy lub do zapobieżenia temu stanowi rzeczy. Widok kogoś, kto szuka zgubionych kluczy do mieszkania w niewłaściwym miejscu, stanowi rację do wskazania mu właściwego miejsca, podobnie jak wiedza o czyimś bólu stanowi rację do podzielenia się z nim środkiem przeciwbólowym. Pomoc w akceptacji zapadnięcia się niebios, gdy nie można go uniknąć, byłby ostatnim powszechnym obowiązkiem podmiotów moralnych stojących w obliczu zagłady. Neutralny charakter ZZN w związku z zasadą analogii powinności i możliwości zależy natomiast od tego, czy jest ona powszechnie prawdziwa. Jeśli tak, to w świetle nadchodzącej katastrofy każdy miałby powód nie tylko do tego, by ją zaakceptować, lecz by również przekonać innych, by nie postępowali wbrew tej zasadzie, próbując łamać normy moralne w celu uniknięcia katastrofy. Ponieważ uzasadnienie tej zasady opiera się na etycznych przesłankach, będzie ono ściśle związane $\mathrm{z}$ drugim elementem fiat iustitia.

\section{Dokonywanie się sprawiedliwości}

To, jak rozumieć „dokonywanie się sprawiedliwości”, jest bardziej skomplikowane niż interpretacja „zapadnięcia się niebios”, zważywszy, że sama kategoria sprawiedliwości jest przedmiotem wielu dyskusji etycznych. W tym miejscu ograniczę się jedynie do wskazania kilku rozróżnień istotnych w kontekście zasady fiat iustitia. Na wieloznaczność słowa ,sprawiedliwość” w kontekście problemów związanych z interpretacją tej zasady zwrócił uwagę Richard Hare. Jego zdaniem powszechne przekonanie, że istnieje przeciwieństwo między sprawiedliwością a użytecznością jest skutkiem braku rozróżnienia znaczeń sprawiedliwości. Hare wyróżnia dwa takie 
znaczenia: sprawiedliwość w sensie ogólnym oraz sprawiedliwość w sensie szczegółowym. Sprawiedliwość w sensie ogólnym jest synonimem słuszności, a zatem określa pozytywną wartość moralną danego czynu. Sprawiedliwość w sensie szczegółowym jest natomiast jedną z wielu moralnych racji, którymi kierujemy się przy podejmowaniu danego działania obok, na przykład, względów miłosierdzia czy konieczności minimalizowania strat. Przy pierwszej interpretacji sprawiedliwości zdanie „,sprawiedliwy, ale niesłuszny" byłoby wyrażeniem wewnętrznie sprzecznym. Biorąc natomiast pod uwagę sprawiedliwość w sensie szczegółowym, można określić dany czyn jako „niesprawiedliwy, ale słuszny jako akt miłosierdzia” lub ,niesprawiedliwy, ale konieczny do uniknięcia straszliwej katastrofy" (Hare, 1977a, s. 144). Hare wskazuje, że brak rozróżnienia tych dwóch znaczeń jest najczęstszym błędem popełnianym przy uzasadnianiu zasady fiat iustitia.

Zwolennicy zasady fiat justitia, ruat caelum rzadko ujawniają, czy wypowiadając słowa „Niech dokona się sprawiedliwość, choćby miały zawalić się niebiosa", posługują się mniej czy bardziej ogólnym znaczeniem słowa ,sprawiedliwość”. Tak więc wykorzystując fakt, że ,sprawiedliwości” W znaczeniu ogólnym nie da się uchylić przez wskazanie jakichkolwiek innych względów moralnych, głoszą nienaruszalną świętość sądów, w których użyto jeden z mniej ogólnych sensów (Hare, 1977a, s. 144).

Jeśli sprawiedliwość ma być rozumiana w sensie ogólnym jako synonim słuszności, to łatwo zauważyć, że interpretacja fiat iustitia będzie zależała od tego, czy przyjmujemy konsekwencjalne, czy deontologiczne rozumienie słuszności. Przyjęcie konsekwencjalnego rozumienia prowadziłoby do uznania omawianej zasady za absurdalną: „Wybieraj najkorzystniejsze działanie, choćby miało ono prowadzić do największych możliwych strat". Absurdalności tej można byłoby przynajmniej w niektórych wypadkach uniknąć poprzez przyjęcie innego znaczenia „zapadnięcia się niebios”. Jeśli będzie ono rozumiane jako śmierć pewnej liczby osób i jeśli dodatkowo przyjmiemy założenie, że śmierć tych osób nie jest najgorszym, co może ich spotkać, wówczas fiat iustitia miałaby zastosowanie w sytuacjach, w których można zdecydować tylko między doprowadzeniem do śmierci tych osób a dopuszczeniem do tego, by żyli ,życiem niewartym przeżycia”. Wówczas przyjęłaby ona brzmienie: „Nie pozwól, by ludzie żyli »życiem nie wartym przeżycia«, choćby wiązało się to z doprowadzeniem do ich śmierci". Problem w tym, że przy takiej interpretacji, paradoksalnie, fiat 
iustitia, ruat coelum, z zasady doradzającej nieliczenie się z kosztami, staje się zasadą nakazującą minimalizowanie strat.

Nie mniej paradoksalne są interpretacje tej zasady zakładające sprawiedliwość w sensie szczegółowym. Jeśli ma być ona rozumiana jako regulacja wzajemnych roszczeń i zobowiązań, to jej główną funkcją jest rozstrzyganie konfliktów związanych z dystrybucją dóbr lub roszczeniem wymierzenia kary (Hare, 1977a, s. 145 i n.). Pierwsza z możliwych interpretacji sprawiedliwości abstrahuje od kategorii interesów, dopuszczając rozstrzygnięcie niekorzystne dla wszystkich stron, lecz formalnie zgodne z ideałem sprawiedliwości. Druga zakłada dokonywanie się sprawiedliwości poprzez bezstronny namysł nad wchodzącymi w konflikt interesami. Zdaniem Hare'a jedynie ta druga koncepcja sprawiedliwości jest zgodna z utylitarystycznym punktem widzenia (Hare, 1977b, s. 104). Wydaje się, że aby zapewnić tę zgodność, sprawiedliwość należy rozumieć jako pewną pozamoralną wartość. Założenie to przyjmuje m.in. Hastings Rashdall, uznając, że sprawiedliwość jest „częścią prawdziwego dobra dla społeczeństwa i każdej jednostki" (Rashdall, 1907, s. 267). Takie rozumienie sprawiedliwości w sensie szczegółowym jest również obecne w następującym fragmencie Principia ethica G.E. Moore'a:

Fiat iustitia, ruat caelum - to powiedzenie można uzasadnić tylko tym, że przez czynienie sprawiedliwości Wszechświat zyskuje więcej, niż straciłby przez zapadnięcie się niebios. Być może, że słuszne jest to przysłowie, w każdym zaś razie twierdzenie, iż sprawiedliwość, pomimo takich następstw, jest naszym obowiązkiem, jest równoznaczne stwierdzeniu przytoczonego tylko co uzasadnienia.

(Moore, 2003: 237)

Interpretacja Moore'a jest podatna na poważne zarzuty. Przede wszystkim jest bardzo mało prawdopodobne, by działanie zgodne z tą zasadą było kiedykolwiek słuszne. Trudno sobie wyobrazić, by działanie prowadzące do katastrofalnych skutków można było uznać w bilansie zysków i strat za najlepsze. Trudno również określić, na czym miałby polegać zysk związany z czynieniem sprawiedliwości. Argumentacja Moore'a daje więc racje raczej dla odrzucenia aniżeli przyjęcia tej zasady - powinniśmy raczej powstrzymać się od czynienia sprawiedliwości, jeśli miałoby to doprowadzić do zapadnięcia się niebios (Butcharov, 2006, s. 370). Wbrew przekonaniu Moore'a zasada fiat iustitia, ruat coelum wskazuje raczej na fakt, że znaczenia zdań 
o obowiązku nie da się bez reszty utożsamić ze znaczeniem zdań o wartości skutków działania (Shaw, 1995, s. 61).

Przynajmniej części powyższych trudności można uniknąć, uznając, że sprawiedliwość jest jednocześnie wartością moralną i pozamoralną, a świat, w którym występuje sprawiedliwość, jest lepszy niż świat bez sprawiedliwości. Warunkiem uznania sprawiedliwości za wartość pozamoralną obok pomyślności, szczęścia lub innych wartości utylitarnych jest to, by nie była ona redukowalna do tych wartości. Ponadto należy założyć możliwość porównania obu tych rodzajów pozamoralnych własności w odniesieniu do przypadków, w których mogą one wchodzić ze sobą w konflikt (Shaw, 1995, s. 38). Zgodnie z powyższymi założeniami zasadę fiat iustitia, ruat coelum należałoby interpretować jako ,jeśli jesteś w sytuacji, w której możesz wybrać jedną z dwóch pozamoralnych wartości: sprawiedliwość i uniknięcie zapadnięcia się niebios, a jednocześnie nie możesz wybrać obu, wybierz sprawiedliwość". Jeśli jednak istnienie świata jest warunkiem istnienia każdej wartości, wówczas zachowanie sprawiedliwości nadal nie spełnia wymogów racjonalności.

Powyższe problemy wydają się główną przyczyną odrzucenia przez konsekwencjalistów omawianej zasady. Interpretacja sprawiedliwości jako słuszności w rozumieniu deontologicznym wydaje się najbliższa historycznego i potocznego sposobu używania omawianej zasady, jednakże nawet jeśli rozumieć fiat iustitia jako nakaz trzymania się uznawanych przez podmiot zasad moralnych, można wskazać co najmniej dwa podstawowe warianty owego nakazu. Pierwsza z możliwych deontologicznych interpretacji „dokonywania się sprawiedliwości” opiera się na słowach Aleksandra Sołżenicyna, wygłoszonych podczas ceremonii wręczenia mu nagrody Nobla, które Jonathan Glover określa jako „zasadę Sołżenicyna”: „Zwykłym krokiem, zwykłego odważnego człowieka jest nie brać udziału w kłamstwie, nie wspierać oszustwa. Niech kłamstwo wejdzie w świat, niech nawet go opanuje, ale nie za moim pośrednictwem" (za: Glover, 1975, s. 184). Zasada Sołżenicyna z pewnością nie może służyć jako interpretacja fiat iustitia, ruat coelum, ponieważ postawiona w niej alternatywa nie dotyczy wyboru między sprawiedliwością a uniknięciem katastrofy, lecz między współudziałem lub brakiem współudziału w kłamstwie. Mimo to, w kontekście poszukiwania znaczenia fiat iustitia, pewne światło na sprawę mogą rzucić słowa ,ale nie za moim pośrednictwem". Jeśli przyjmiemy, że racje stojące za fiat iustitia mają charakter zogniskowany na podmiocie, to zasadę analogii powinności 
i możliwości można byłoby uznać za indywidualne kryterium racjonalności praktycznej (,fakt, że moje działanie jest zakazywane przez absolutną normę moralną, powinien być traktowany tak jak brak możliwości wykonania tego działania"). Klasyczny argument przeciwko tej tezie głosi, że osoba, która zamiast o życie innych troszczy się przede wszystkim o własne wnętrze, wykazuje egoistyczną nadwrażliwość (self-indulgent squeamishness) (Williams, 1973, s. 102). Bernard Williams, analizując ten zarzut, zwraca uwagę, że aby uznać kogoś za pobłażliwego względem siebie, należałoby stwierdzić, że nie postępuje on ze względu na szlachetne motywy, ani nawet ze względu na chęć postępowania tak, jak postąpiłaby w danej sytuacji osoba szlachetna, lecz ze względu na przyjemność czerpaną z ujawnienia swojej szlachetności (Williams, 1995, s. 47). Powstrzymywanie się od złamania głęboko i szczerze wyznawanych zasad moralnych nie jest jednak tym samym, co pobłażliwość względem siebie. Co więcej, zdaniem Williamsa, nawet jeśli jakieś nasze uczucia miałyby prowadzić do działania sprzecznego z zasadą użyteczności, nieuzasadnione byłoby potępienie osoby posiadającej owe uczucia, podobnie jak nieuzasadnione byłoby nakazanie jej działania sprzecznego z owymi uczuciami (Williams, 1973, s. 103 i n.).

Można przypuszczać, że zasada fiat iustitia, ruat coelum będzie wyznawana przez ludzi, w których moralnym życiu dominują owe nieutylitarne uczucia. Absolutystyczną postawę trudno jednak byłoby usprawiedliwić, gdyby podmiot odrzucał racje za akceptacją katastrofy. Człowiek wyznający zasadę „to nie ja złamię zasady sprawiedliwości, choćby niebiosa miały runąć" może nie mieć nic przeciwko temu, by inni je łamali, jeśli pozwoli to na uniknięcie katastrofy, jednak koncentruje się na tym, z czym on sam może lub nie może żyć. O ile jednak w wypadku trzymania się zasad sprawiedliwości kosztem własnej śmierci postawa może budzić podziw, to w wypadku trzymania się własnych zasad z nadzieją, że inni ludzie złamią swoje lub że kierują się innymi zasadami, może być uznana za zbyt słabo uzasadnioną.

Istnieją jednak racje za tym, by nie sprowadzać fiat iustitia wyłącznie do roli prywatnej maksymy. Człowiek, który uznaje jakieś działanie za niesłuszne, ma powody, by uznać je również za niesłuszne dla wszystkich innych znajdujących się w podobnych okolicznościach, co otwiera drogę do uniwersalnej interpretacji. W kontekście poszukiwania zasad politycznych umożliwiających osiągnięcie wiecznego pokoju Kant podaje następującą interpretację omawianej zasady: „Niech zapanuje sprawiedliwość, a przez to wszystkie szelmy na świecie niech zginą” (Kant, 1995, s. 75). Pierwszym, 
co narzuca się w tej interpretacji, jest zmiana drugiego elementu zasady poprzez ograniczenie jej do istnienia złoczyńców. Według Sisseli Bok argumentacja Kanta stanowi wybieg polegający na tym, że główna absolutystyczna intuicja zostaje ukryta pod tezami dotyczącymi sprawiedliwości retrybutywnej i połączona z trudną do zakwestionowania tezą, że ,[ś]wiat w żadnym wypadku nie zginie przez to, że będzie na nim mniej złoczyńców" (Kant, 1995, s. 76), które mają uzasadnić, że konflikt między polityką i moralnością istnieje wyłącznie ze względu na egoistyczne ludzkie skłonności (Bok, 1988, s. 12). Co więcej, nawet gdyby interpretować fiat iustitia jako zasadę dotyczącą wymierzenia kar, nie będzie ona wolna od kontrowersji. Szczegółowego zastosowania tej zasady upatruje się w sformułowanym przez Kanta przykładzie obowiązku stracenia ostatniego skazańca tuż przed rozwiązaniem społeczności (Kania, 2018, s. 95; Kuźmicz, 2006, s. 81): „[...] by zmyta została krew, która splamiłaby cały lud, gdyby odstąpiono od wykonania kary. W przeciwnym razie lud byłby współwinny tej publicznej obrazy sprawiedliwości” (Kant, 1797/2005, s. 181). Sprowadzenie fiat iustitia do zasady nakazującej eliminację złoczyńców byłoby jednak zbyt dużym uproszczeniem. Kant umieszcza wprawdzie powyższy przykład w kontekście sprawiedliwości retrybutywnej, jednak jego założenia dotyczą sensu istnienia ludzkości w ogóle: „Jak głosi faryzejskie porzekadło, »lepiej niech zginie jeden, niż gdyby wymrzeć miał cały lud«; lecz kiedy upada sprawiedliwość, to dalsze stąpanie ludów po tym świecie nie ma już właściwie znaczenia" (Kant, 1797/2005, s. 179). W tym fundamentalnym znaczeniu fiat iustitia głosi, by każdy podmiot i ludzkość jako całość byli wolni od moralnego zła. Wyzwaniem dla tej interpretacji będzie wyjaśnienie, czy powyższa racja jest przynajmniej w niektórych wypadkach wystarczająca do zaakceptowania upadku niebios.

\section{Kiedy sprawiedliwość zwycięża nad katastrofą}

Z powyższych analiz wynika, że najbardziej zgodną z przynajmniej niektórymi moralnymi intuicjami interpretacją zasady fiat iustitia, ruat coelum jest ta, która zakłada zasadę analogii powinności i możliwości, przyjmuje ogólne rozumienie sprawiedliwości oraz istnienie absolutnych wymogów moralnych. Interpretacja ta brzmi następująco: 
Fiat iustitia, ruat coelum - należy raczej zaakceptować katastrofę niż dążyć do jej uniknięcia, jeśli jedynym sposobem pozwalającym jej uniknąć jest podjęcie działań, które łamią pewien absolutny wymóg moralny.

Wydaje się, że jednym z elementów naszego moralnego patrzenia na świat jest przekonanie, że sprawiedliwość prowadzi lub powinna prowadzić do dobra. To przekonanie jest nie mniej głębokie niż to, że z niesprawiedliwości wynika zło. Tragiczne sytuacje, których dotyczy fiat iustitia, pokazują jednak, że nie ma koniecznego związku między tymi elementami. W niektórych sytuacjach dążenie do przestrzegania absolutnych norm prowadzi do pogłębienia problemów moralnych, co ilustruje tzw. paradoks deontologizmu (Kamm, 2006, s. 26 i n.; Scheffler, 1982, s. 188). Krzysztof Saja ilustruje ten paradoks przykładem zatytułowanym „dylemat epidemii”, w którym wirusolog staje przed wyborem poświęcenia życia jednego pacjenta, by stworzyć dawkę pozwalającą wyleczyć pięć osób i wyeliminować ryzyko epidemii. Jeśli odda decyzję w ręce komisji bioetycznej, ta stanie przed wyborem zabicia dziesięciu osób w celu uratowania stu i zapobiegnięcia dalszego rozprzestrzeniania się choroby. Przesunięcie decyzji na jeszcze wyższy szczebel będzie oznaczać konieczność poświęcenia tysiąca osób (Saja, 2015, s. 193 i n.). Zgodnie z zarzutem odwołującym się do paradoksu deontologizmu, nieracjonalne jest zaakceptowanie mniejszej ilości zła niż większej, przy czym zło może być rozumiane nie tylko jako utrata życia, lecz również złamanie zasad moralnych. Saja podsumowuje ów zarzut następująco: „Jeśli traktowanie osób jedynie jako środka do celu jest moralnie złe, dlaczego nie jest racjonalnym działanie, które zmniejsza ilość takich sposobów traktowania ludzi? Jeśli tym, co moralnie złe, jest zamiar czynienia zła, dlaczego niekiedy nie powinniśmy mieć takiego zamiaru, aby dziesięć innych osób mogło mieć czyste sumienie?" (Saja, 2015, s. 193). Tradycyjną odpowiedzią na ów zarzut ze strony deontologizmu jest przywoływane wcześniej założenie o tym, że wartości moralnej nie można traktować jak przeliczalnych wartości pozamoralnych oraz teza o analogii powinności i możliwości. Przykład Sai pokazuje jednak, że nawet przyjąwszy te założenia, absolutysta nie unika problemu racjonalnego uzasadnienia swojej decyzji. Jeśli Jan nie podejmie samodzielnej decyzji, spowoduje konieczność podjęcia jej przez kolejne podmioty. Wyraźna w omawianej sytuacji kumulatywność negatywnych skutków związanych z przestrzeganiem absolutnych norm moralnych będzie powodować, że coraz więcej osób będzie stało przed coraz trudniejszym problemem moralnym. Absolutysta może stwierdzić, 
że trudnością w tym wypadku nie jest samo przekazywanie decyzji w ręce innych ludzi, ile kumulatywność polegająca na konieczności poświęcenia coraz większej liczby osób. Fakt kumulatywności może jednak zostać wykorzystany do obrony absolutystycznej intuicji. Konieczność zwiększenia zła moralnego przez zabicie coraz większej liczby osób sprawia, że siła absolutystycznych racji rośnie, przyjmując największą wartość w sytuacji, w której konieczne jest dokonanie ogromnego zła. Zależność tę ilustruje poniższy przykład:

Drugi dylemat epidemii: wybucha epidemia, która zagraża istnieniu całego gatunku ludzkiego. Pewien lekarz szczęśliwym zbiegiem okoliczności odkrywa, że jego dziesięcioletni pacjent jest odporny na infekcję. Szybko okazuje się, że jest on jedyną odporną osobą na świecie. Aby uniknąć katastrofalnych skutków, lekarz musi dokonać eksperymentów na tym pacjencie, co zakończy się jego śmiercią. Załóżmy, że lekarz ma tylko dwie opcje: albo dokonać tego eksperymentu, albo stanąć w obronie pacjenta w ten sposób, że każdy, kto będzie chciał zabić pacjenta, będzie musiał również zabić i jego. Jeśli stanie w obronie pacjenta, każda kolejna osoba, która może mieć wpływ na sytuację, będzie również mieć tylko dwie opcje: stanąć w obronie lekarza i pacjenta lub ich zabić. Każda osoba podejmująca decyzję o stanięciu w obronie pozostałych zwiększa liczbę osób, które należałoby zabić w celu uniknięcia globalnej katastrofy. Ostatni z podmiotów podejmujących decyzję stanie przed wyborem, czy zabić wszystkich ludzi z wyjątkiem jednego, którego może uratować, czy zaakceptować śmierć wszystkich.

W powyższym przykładzie zwiększanie liczby osób, których życie należałoby poświęcić w celu uniknięcia katastrofy, wydaje się wzmacniać absolutystyczną intuicję. Ostatni podmiot podejmujący decyzję ma silne racje za tym, by nie dokonywać masowego zabójstwa dla uratowania jednej osoby. Fakt, że bez tego ogromnego moralnego zła wszyscy i tak zginą, może być w tych okolicznościach niewystarczający do jego uzasadnienia. Ostateczny koniec ludzkości będzie się wiązał w tym scenariuszu z zaakceptowaniem tragedii i solidarną wiernością moralnym nakazom.

Powyższe uzasadnienie nadal jest narażone na zarzut nieracjonalności z kilku powodów. Po pierwsze można stwierdzić, że wzrost siły absolutystycznej intuicji jest pozorny i wynika z wyłącznie malejącej siły racji za uniknięciem katastrofy. Z konsekwencjalnego punktu widzenia można uznać, że siła UZN jest wyznaczona przez różnicę między liczbą osób, których życie należy poświęcić, a ogólną liczbą osób zagrożonych przez katastrofę. 
Siła UZN byłaby maksymalna wtedy, gdy można byłoby uratować wszystkich, nie zabijając nikogo, i zerowa wtedy, gdy liczba osób, które trzeba poświęcić, jest równa ogólnej liczbie osób ratowanych. Przy tym założeniu siła UZN w obu przykładach epidemii maleje, zaś siła ZZN wzrasta, ale nie ma to nic wspólnego z wiernością zasadom moralnym. Nawet jeśli uznamy, że w sytuacji ostatniego podmiotu podejmującego decyzję ZZN będzie bardziej uzasadniona, to tylko $\mathrm{w}$ porównaniu $\mathrm{z}$ całkowicie nieracjonalną decyzją lekarza i stopniowo mniej nieracjonalnymi decyzjami kolejnych podmiotów. Co więcej, nawet w sytuacji ostatniego podmiotu maksymalna siła racji ZZN nigdy nie przewyższy siły racji UZN, gdyż istnienie jednej osoby będzie nadal bardziej wartościowe niż pozwolenie na śmierć wszystkich. Drugi dylemat epidemii jest odwróceniem tradycyjnej dyskusji między przeciwnikami i zwolennikami absolutyzmu. Pierwsi będą pokazywać, że życie jednej osoby będzie miało wartość rozstrzygającą omawiany dylemat, drudzy - że liczba osób, które w fundamentalny sposób byłyby skrzywdzone, sprzyja ZZN.

Argument stojący za fiat iustitia nie opiera się jednak na proporcji zachodzącej między liczbami osób zagrożonych śmiercią w poszczególnych opcjach wyboru. Zmiana kontekstu pokazuje, iż za ZZN stoi założenie, że w obliczu perspektywy katastrofy lub jej uniknięcia ważna jest nie tylko wartość rezultatu, lecz również sposób, w jaki ludzkość spotka swój koniec. Odniesienie do sposobu zakończenia istnienia ludzkości może odwoływać się do oceny całej historii rodzaju ludzkiego. Akceptacja katastrofy polegałaby na uznaniu, że historia, w której ludzkość ginie w sposób naturalny lub heroiczny, jest bardziej godna wyboru niż ta, w której prawie wszyscy umierają z powodu intencjonalnych działań, takich jak wojna lub masowe zabójstwo ${ }^{4}$. Racja ZZN jest w tym ujęciu rozszerzoną racją za braniem pod uwagę historii całego życia jednostki, zakładającą, że sposób, w jaki odchodzimy, może rzutować na ocenę życia jako całości ${ }^{5}$. Decyzja o zaakceptowaniu końca gatunku ludzkiego byłaby analogiczna do decyzji definiujących całe życie podmiotu, które Ronald Dworkin opisuje w kategorii krytycznych interesów

4 ZZN można byłoby zgodnie z tą propozycją uznać za podstawę absolutystycznej racji opartej na wzorcach. Kategorię tę wprowadził Christopher Woodard (2008). Według niego racje tego typu są to racje do działania, które przyczynia się do realizacji pewnego moralnie słusznego wzorca. Racje te mogą istnieć nawet wówczas, gdy inni ludzie nie podejmują działań koniecznych do jego realizacji.

5 Rację tę w kontekście bioetycznym analizuje Frances M. Kamm (2013: 21 i n., 407). 
(Dworkin, 1993, s. 203 i nn.). Powyższą argumentację wzmacnia fakt, że w omawianych okolicznościach w przypadku wybrania ratunku jednej osoby, jej życie nie będzie pozwalać ani na odtworzenie ludzkości, ani na odkupienie dokonanego zła. Fiat iustitia, rozumiana jako sposób wyboru moralnie doniosłego zakończenia historii ludzkości, wymaga jednak nie tylko przyjęcia założenia, że racja wierności moralnym zasadom należy lub jest analogiczna do racji opartych na krytycznych interesach, lecz również, że jest ona powszechna. Tylko wówczas możliwe byłoby stosowanie tej zasady nie tylko w skrajnie mało prawdopodobnych okolicznościach opisywanych przez drugi dylemat epidemii, lecz również wtedy, gdy uratować można znacznie więcej osób i gdy nie można założyć, że większość ludzi zgodzi się na poświęcenie swojego życia. Tu jednak absolutystyczna intuicja napotyka na kolejny problem.

Drugim argumentem przeciwko uznaniu absolutystycznej intuicji jest to, że siła ZZN nie wynika z absolutnego charakteru norm moralnych, lecz z faktu, że każdy kolejny podmiot godził się na narażenie swojego życia, by uratować przez zabiciem pozostałych. Jeśli przyjmie się założenie, że zapadnięcie się niebios będzie dotyczyć nie tylko podmiotów zdolnych do podejmowania decyzji, lecz również osób pozbawionych takiej możliwości, istot pozaludzkich czy wreszcie tych, którzy preferują ocalenie ponad stanięciem w obronie innych, to siła ZZN drastycznie maleje. W tych okolicznościach kolejne osoby stające w obronie poprzednich stawiają na szali nie tylko swoje własne życie, lecz życie ludzi pozbawionych możliwości podejmowania decyzji. Nawet jednak jeśli ograniczymy stosowanie fiat iustitia do sytuacji, w których każdy może podjąć decyzję, w mocy pozostanie zarzut, że zasada ta co najwyżej uzasadnia dopuszczalność zaakceptowania nieracjonalnego poświęcenia życia, na które wszyscy się zgodzili. W świetle tego zarzutu drugi dylemat epidemii nie różniłby się od sytuacji, w której każdy podmiot kolejno wybiera śmierć zamiast odżywiania się owadami, chociaż stanowi to jedyny sposób na przetrwanie ludzkości. Powszechna zgoda pozwala na zastąpienie w omawianej zasadzie słowa iustitia przez dowolne inne słowo wyrażające kategoryczne interesy ludzkości w danych okolicznościach. Zgodnie z tym zarzutem drugi dylemat epidemii pokazuje jedynie, że możliwe są decyzje będące jednocześnie heroiczne i nieracjonalne. Za heroizmem wyrażanym przez fiat iustitia nie stoją jednak racje, lecz emocje, które odczuwalibyśmy zawsze, gdy ktoś poświęcałby się dla dobra innych bez względu na koszty. Podobne emocje 
moglibyśmy odczuwać na wieść o tym, że sto osób poświęciło swoje życie, by ocalić życie jednej. Sposobem obrony absolutystycznej intuicji byłoby stwierdzenie, że dzięki zasadzie możliwości i powinności deontologizm unika paradoksu. Uniknięcie większej liczby przypadków złamania norm moralnych nie jest w optyce absolutystycznej możliwe, gdyż opcja, która by na to pozwalała, jest niewidoczna. Założeniem zastosowania fiat iustitia do drugiego dylematu epidemii jest to, że istnieje racja za stanięciem w obronie niewinnego pacjenta i osób, które już podjęły taką decyzję, oraz że racja ta może co najmniej w pewnych okolicznościach być silniejsza niż racje za uniknięciem katastrofy.

\section{Podsumowanie}

Można powiedzieć, że zasadą, która zrobiła największą karierę w historii etyki, jest Złota Reguła. Pozwala ona nie tylko odkryć moralną doniosłość przyjęcia perspektywy innych osób, lecz również rozstrzygnąć codzienne praktyczne problemy w dość jasno określonym zakresie, w którym wchodzą w grę powszechne i niezależne od subiektywnych uwarunkowań dobra. Fiat iustitia radzi sobie znacznie gorzej. O ile w aspekcie teoretycznym umożliwia ona na wyrażenie absolutystycznej intuicji, o tyle znacznie trudniej jest wskazać taką interpretację, która pozwalałaby na rozstrzygnięcie praktycznych problemów. Sytuacja przedostatniego podmiotu moralnego decydującego, czy zabić pozostałych dla uratowania jednej osoby wydaje się skrajnie mało prawdopodobnym scenariuszem zarówno ze względu na okoliczności, jak i na założenie, że niemal wszyscy kierowaliby się większą wzajemną troską o poszanowanie fundamentalnych praw niż o szanse przeżycia. Pokazuje ona jednak, że możliwość uznania fiat iustitia za regułę praktyczną zależy przede wszystkim od tego, czy ludzie są podmiotami moralnymi, zdolnymi do jej stosowania.

\section{Bibliografia}

Bentham, J. (1789/2005). An Introduction to the Principles of Morals and Legislation. Red. J.H. Burns, H.L.A. Hart. Oxford: Clarendon Press.

Butcharov, P. (2006). Ethics dehumanized. W: T. Hogan, M. Timmons (red.), Metaethics after Moore (s. 367-390). Oxford: Clarendon Press. 
Donagan, A. (2014). The Theory of Morality. Chicago: University of Chicago Press.

Dworkin, R. (1993). Life's Dominion: An Argument about Abortion, Euthanasia and Individual Freedom. New York: Alfred A. Knoppf.

Fried, Ch. (1978). Right and Wrong. Cambridge, MA: Harvard University Press.

Glover, J., Scott-Taggart, M. (1975). It Makes No Difference Whether Or Not I Do It. Proceedings of the Aristotelian Society, Supplementary Volumes, 49, 171-209.

Hare, R. (1977a). Sprawiedliwość i równość. Etyka, 15, 143-144.

Hare, R. (1977b). Freedom and Reason. Oxford: Clarendon Press.

Jonas, H. (1996). Zasada odpowiedzialności. Tłum. M. Klimowicz. Kraków: Platan.

Kamm, F.M. (2006). Intricate Ethics. Rights, Responsibilities and Permissible Harm. Oxford: Oxford University Press.

Kamm, F.M. (2013). Bioethical Prescriptions. To Create, End, Choose and Improve Lives. Oxford: Oxford University Press.

Kant, I. (1979/2005). Metafizyka moralności. Tłum. E. Nowak. Warszawa: Wydawnictwo Naukowe PWN.

Kant, I. (1795/1995). O wiecznym pokoju. Tłum. F. Przybylak. Wrocław: Wydawnictwo Uniwersytetu Wrocławskiego.

Liebs, D. (2014). Das Rechtssprichwort Fiat iustitia et pereat mundus. Revue Internationale des Droits de l'Antiquité, 61, 83-95.

Mansfield, W.M. R. v. Wilkes 4 Burr 2527 [98 ER 327], 1770.

Moore, G.E. (1903/2003). Zasady etyki. Tłum. C. Znamierowski. Warszawa: Altaya DeAgostini.

Rashdall, H. (1907). The Theory of Good and Evil. Vol. 1. Oxford: Clarendon Press.

Radbruch, G. (1937). O celu prawa. Ruch Prawniczy, Ekonomiczny i Socjologiczny, 3, 325-336.

Saja, K. (2015). Etyka normatywna: między konsekwencjalizmem a deontologia. Kraków: Universitas.

Scheffler, S. (1982). The Rejection of Consequentialism. Philosophical Investigation of the Considerations Underlying Rival Moral Conceptions. New York: Oxford University Press.

Scheler, M. (1923/1976). O zjawisku tragiczności. W: Arystoteles, D. Hume, M. Scheler, O tragedii i tragiczności. Tłum. W. Tatarkiewicz, T. Tatarkiewiczowa, R. Ingarden (s. 49-95). Kraków: Wydawnictwo Literackie. 
Shaw, W.H. (1995). Moore on Right and Wrong: the Normative Ethics of G.E. Moore. Dordrecht-Boston: Kluwer Academic Publishers.

Sidgwick, H. (1907). The Methods of Ethics. London: Macmillan and Company.

Watson, W. (1602/1974). A Decacordon of Ten Quodlibetical Questions concerning Religion and State. IIkley: Scolar Press.

Wheeler, A.M. (1986). Donagan on fiat iustitia, ruat caelum. Ethics, 4 (96), 873-875.

Williams, B. (1973). Against Utilitarianism. W: B. Williams, J.J.C. Smart, Utilitarianism For and Against (s. 75-150). Cambridge: Cambridge University Press.

Williams, B. (1995). Utilitarianism and Self-Indulgence. W: B. Williams, Moral Luck (s. 20-53). Cambridge: Cambridge University Press.

Woodard, Ch. (2008). Reasons, Patterns and Cooperation. London-New York: Routledge.

Zajadło, J. (2013). Łacińska terminologia prawnicza. Warszawa: Wolters Kluwer.

\section{THE PROBLEM OF INTERPRETATION OF THE PRINCIPLE FIAT IUSTITIA, RUAT COELUM}

\section{Summary}

Most of the consequential and deontological interpretations of the fiat iustitia, ruat coelum principle, do not allow treating it as a basis for resolving practical problems. This article presents a proposal for an interpretation, under which this principle can serve as a practical rule. This interpretation assumes that fiat iustitia, ruat coelum applies to the final decision that affects the assessment of the entire life of the agent or humanity. Success of this interpretation depends on whether the lack of morally permissible possibilities to avoid individual or global catastrophe may serve as a reason for accepting it. 